\title{
Geography determines genetic relationships between species of mountain pine (Pinus mugo complex) in western Europe
}

\author{
Myriam Heuertz , Jennifer Teufel , Santiago C. González-Martínez,
} Alvaro Soto , Bruno Fady, Ricardo Alía and Giovanni G. Vendramin

Evolutionary Biology and Ecology, Factité des Sciences, Universite Libre de Bruxelles, cpI60/ I2, av. F.D. Roosevelt 50, 1050 Brussels, Belgium, Department of Forest Systems and Resources, Centre of Forest Research CIFORINIA, Carretera de la Coruna km 7.5, 28040 Madrid, Spain, Öko-Iistitut e.V., Institute for Applied Ecology, Postfach 6226, D-79038 Freiburg, Germany, U.D. Anotomic, Fisiologia y Genética, Departamento Silvopascictultura, Universidad Politécnica de Modrid, E.T.S.J. de Montes, Ciudad Universitario, s/n. 28040 Modrid, Spain, INRA, UR629, Evologie des Forîts Méditerranéenties, Domaine St Pand, Site Agroparc, F-84914 Avignon, France, Consiglio Nazionale delle Ricerche, Istituto di Genetica Vegetale, Via Madonna del Piano 10,50019 Sesto Fiorentino (Firenze), Italy

\begin{abstract}
Aim Our aims were to test whether morphological species of mountain pines were genetically supported in the western part of the distribution range of the Pinus mugo species complex (Pinus mugo Turra sensu lato), to resolve genetically homogeneous clusters of populations, to determine historical demographic processes, and to assess the potential hybridization of mountain pines with Scots pine, Pinus sylvestris $\mathrm{L}$.

Location Populations were sampled in the Iberian System, the Pyrenees, the French Mont Ventoux, Vosges and Jura mountains, the German Black Forest and throughout the Alps. This corresponded to a range-wide sampling for mountain pine sensu stricto (Pinus uncinata $\mathrm{Ram}$.) and to a sampling of the western parts of the ranges of dwarf mountain pine (Pinus mugo Turra sensu stricto) and bog pine/peatbog pine [Pinus rotundata Link/Pinus $\times$ pseudopumilio (Willk.) Beck].
\end{abstract}

Methods In total, 786 individuals of $P$. mugo sensu lato from 29 natural populations, and 85 individuals of $P$. sylvestris from four natural populations were genotyped at three chloroplast microsatellites (cpSSRs). Populations were characterized for standard genetic diversity statistics and signs of demographic expansion. Genetic structure was explored using analysis of molecular variance, differentiation statistics and Bayesian analysis of population structure (BAPS).

Results One hundred haplotypes were identified in $P$. mugo sensu lato. There was a stronger differentiation between geographical regions than between morphologically identified taxa $(P$. mugo sensu stricto, $P$. uncinata and $P$. rotundata $/ P . \times$ pseudopumilio $)$. Overall genetic differentiation was weak $\left(G_{S T}=0.070\right)$ and displayed a clear phylogeographic structure $\left[N_{\mathrm{ST}}=0.263, N_{\mathrm{ST}}>N_{\mathrm{ST}}\right.$ (permuted), $P<0.001]$. BAPS identified a Pyrenean and an Alpine gene pool, along with several smaller genetic clusters corresponding to peripheral populations.

Main conclusions The core regions of the Pyrenees and Alps were probably recolonized, respectively by $P$. uncinata and $P$. uncinata/P. mugo sensu stricto, from multiple glacial refugia that were well connected by pollen flow within the mountain chains. Pinus rotundata $/ P . \times$ pseudopumilio populations from the Black Forest, Vosges and Jura mountains were probably recolonized from various glacial populations that kept their genetic distinctiveness despite late glacial and early Holocene expansion. Marginal P. uncinata populations from the Iberian System are compatible with elevational shifts and long-term isolation. The causes of haplotype sharing between $P$. mugo sensu lato and $P$. sylvestris require further research.

\section{Keywords}

Chloroplast microsatellites, conservation, genetic clusters, haplotype sharing, historical demography, hybridization, Pinus mugo complex, Pinus sylvestris, post-glacial recolonization, western Europe. 


\section{INTRODUCTION}

The Pleistocene climate oscillations affected the distribution of genetic variation within plant species in complex ways (Petit et al., 2003; Tribsch \& Stuessy, 2003). During the cold stages, some cold-adapted tree species of the Northem Hemisphere were not restricted to southern glacial refugia but maintained fairly extensive populations close to the ice sheets (Tarasov et al. 2000). These populations expanded during warm stages and experienced extensive gene flow (Maliouchenko et al., 2007). As a consequence, woody species with boreal-temperate contemporary distributions show significantly lower genetic differentiation at maternally inherited markers than species that were restricted to southern glacial refugia (Petit et al, 2003; Aguinagalde et al, 2005). At lower latitudes, in contrast, cold-adapted tree species commonly thrived in the mountain foothills during cold stages and migrated to higher elevations during warmer interglacials (Davis \& Shaw, 2001; RobledoAmuncio et al, 2005). Decreased gene flow and increased genetic drift may produce substantial differentiation among such interglacial bigh-mountain populations (Robledo-Arnuncio et al., 2005), leading even to speciation events (AguirrePlanter et al., 2000; Jaramillo-Correa et al, 2008).

Pinus mugo Turra sensu lato (s.l.), the mountain pine complex, is a very polymorphic species complex with a montane distribution in southern and central Europe, in which 16 species, 91 varieties and 19 forms had been described prior to the taxonomic revision of Christensen (1987a). The delimitation of taxa is difficult because of a high morphological variability in growth habit (single versus multi-stemmed, erect versus prostrate), cone and needle characters (Christensen, 1987a,b; Boratyńska \& Boratyński, 2007, and references therein; Marcysiak \& Boratyński, 2007), and possible hybridization with Scots pine, Pinus sylvestris L. (Christensen, 1987a,b; Wachowiak \& Prus-Glowacki, 2008). Taxonomic resolution has also been impaired because many studies examined only small parts of the complex's distribution range or made unsuitable interpretations of phenotypic traits or taxon names (see Businský, 1999; Hamerník \& Musil, 2007). At present, the two most complete revisions of the group differ in their conclusions: Christensen (1987a,b) recognized two subspecies, Pinus mugo Turra ssp. migo and P. mugo Turra ssp. uncinato (Ram.) Domin, and one 'hybrid taxon', P. mugo Turra nothossp, rotundata (Link) Janchen \& Neumayer, which he believed to have arisen from hybridization between the other two species. Businský (1999) listed Pinus mugo Turra, Pints uncinata Ramond and Pints rotundata Link as separate species. Hamerník \& Musil (2007) provided comparative tables for the taxon names used in the literature to refer to specific morphologies and distribution ranges, and here we follow their nomenclature (see figures 2 and 3 in Hameník \& Musil, 2007, for growth habit and cone morphology, and figures 4 and 5 in Hamerník \& Musil, 2007, for distribution ranges). Pinus uncinata Ramond, mountain pine sensu stricto (s.s.), is usually a monocormic (single-stemmed) tree with asymmetrical cones and grows in the subalpine vegetation belt up to the upper forest limit, and even up to the upper tree limit (1000-2300 m elevation) in the western part of the range of the complex. It is found in the Iberian System (Sierra de Gúdar and Sierra de Cebollera) in Spain, the Pyrenees, the Massif Central, the Mont Ventoux and the western Alps (Cantegrel, 1983; Christensen, 1987a; Hamerník \& Musil, 2007). It overlaps with Pinus mugo Turra s.s., dwarf mountain pine, in eastern Switzerland and western Austria, where transitive forms occur. The latter has a shrubby (polycormic) growth habit and symmetrical cones, and forms large mats in subalpine habitats of the eastern Alps, the Erzgebirge, the Dinaric Alps, the Carpathians and the Rila and Pirin mountains of Bulgaria, with an isolated population in the Italian Apennines and other outlier populations in the western Alps (Christensen, 1987a; Hamerník \& Musil, 2007). Pints rotundata Link, bog pine, is ecologically highly specialized to peat bog habitats and occurs in the northern part of the distribution range, from the German Black Forest in the west to the Polish Table Mountains in the east. It is generally monocormic and has weakly to strongly asymmetrical cones. A common synonym used mostly for eastern European bog pine is Pinus uliginosa Neumann (Businský, 1999; Hamerník \& Musil, 2007), although recent work suggests that $P$. rotindato and $P$. uliginosa might be distinct species (Businský \& Kirschner, 2006). Polycormic specimens of different heights (sometimes even prostrate) found mainly on raised bogs are thought to be of hybrid origin between $P$. rotundata and P. mugo s.s. and are classified as Pinus $\times$ pseudopumilio (Willk.) Beck, peatbog pine (Businský, 1999; Hamerník \& Musil, 2007). Pinus sylvestris is closest to P. uncinata with respect to needle sclerenchyma characters (Boratyíska \& Boratyniski, 2007), whereas its cone morphology more dosely resembles that of P. migo s.s. (Christensen, 1987b; Marcysiak \& Boratyński, 2007). Divergence within the P. mugo species complex is thought to have initiated in the Pliocene, when increased ice and snow cover in the Alps broke up a large distribution range, leading to separation into individual Pleistocene refugia (Sandoz, 1983; Christensen, 1987a).

The location of glacial populations of the $P$. mugo complex is poorly known to date because P. migo s.l. pollen is very similar to that of the more common P. sylvestris and Pinus nigra, and therefore palynological records seldom distinguish these species (Willis et al. 1998). Even macrofossil remains are often not sufficiently well preserved to enable unambiguous identification of P. mugo and P. sylvestris (García-Amorena et al, 2007). In the Iberian Peninsula, fossil pollen indicates glacial populations of $P$. sylvestris/ $P$. mugo in the Cantabrian Atlantic Mountains, in the Iberian System - including the Sierra de Cebollera, where P. uncinata grows today (Franco Múgica et al., 1998; Ramil-Rego et al., 1998; Gil García et al., 2002), in eastern Spain (Carrión, 2002), and in the Betic System (Pons \& Reille, 1988). Fossil P. sylvestris/P. mugo trunks dated from c. 20,000 to $c .34,000 \mathrm{yr}$ BP indicate refugia on the Portuguese coast (Garcia-Amorena et al, 2007). Glacial refugia existed very probably in the Alps, where travertine formations dated to $11000-10000$ уг вP unambiguously reveal cone imprints of $P$, uncinata (in the southern French Alps at 
$2200 \mathrm{~m}$ elevation, Ali et al., 2003) and of P. uncinata and P. mugo s.s. (in the Susa Valley, Italy at c. 1300 and $1900 \mathrm{~m}$ elevation, Ali et al., 2006). Fossil pollen records additionally suggest $P$. sylvestris/P. mugo presence up to $c .1400 \mathrm{~m}$ elevation in the Swiss central and southern Alps during the Oldest Dryas (15,000-13,000 yr BP, Burga, 1988). In eastern Europe, Feurdean et al. (2007) reported that P. mugo formed part of the late glacial $(14,700 \mathrm{yr} \mathrm{BP})$ vegetation at mid-altitude in the Carpathians, based on fossil pollen. Furthermore, P. mugo charcoal remains prove the glacial-period presence on several sites at latitudes as far north as the Czech Republic $\left(48.87^{\circ} \mathrm{N}\right.$, Willis \& van Andel, 2004). The fossil pollen studies clearly show a wider natural range and higher levels of $P$. sylvestris/ $P$. mugo pollen representation than at present, suggesting an early range-wide post-glacial expansion starting about 13,000 yr вP (Burga, 1988; Ramil-Rego et al., 1998; Rösch, 2000; Gil García et al., 2002; Cheddadi et al., 2006; Feurdean et al., 2007). Milder temperatures than those of the Last Glacial Maximum (LGM, 18,000 $\mathrm{yr} \mathrm{BP}$ ) were common during the Weichselian glacial stage $(110,000-10,000 \mathrm{yr}$ вP, van Andel, 2002; Van Meerbeeck et al., 2009), so that numerous P. sylvestris/P. mugo populations could have been supported (see also West, 1980; Field et al., 2000). Given that today $P$. uncinata and P. mugo s.s. are species of the subalpine vegetation, the interglacial retreat to high elevations may also have played an important role in shaping their genetic structure.

In the last few decades, $P$, mugo s.l, populations have started expanding into higher elevations in response to decreased grazing pressures and climate warming (Ozenda, 1988; Camarero et al., 2005; Dirnböck et al., 2008). Upslope migration is also observed in species that occur in the subalpine vegetation belt below, and occasionally in sympatry with P. mugo s.l., such as P. sylvestris and the more shade-tolerant Picea abies (Ozenda, 1988; Camarero et al., 2005). The upward pressure by $P$. sylvestris is especially important in marginal populations of $P$. uncinata that have already reached the mountain tops of low mountains in Spain (Camarero et al., 2005). Pinus sylvestris and P. mugo s.l. are partially interfertile (Schmid \& Bogenrieder, 1998; Wachowiak et al., 2005), although the natural extent of introgression between them appears to be low (Christensen, 1987b). The sub-optimal growth conditions of the marginal $P$. uncinata populations and the competition and potential hybridization with $P$. sylvestris may represent a significant threat to their conservation. Furthermore, if marginal $P$. uncinata populations are genetically distinct from core populations, their loss may represent a significant diminution of diversity and adaptive potential for the species (Hampe \& Petit, 2005; Eckert et al., 2008).

In this paper we investigate the distribution of genetic diversity in $P$. uncinata and its genetic relationships with P. rotundata/P. $\times$ pseudopumilio and P. mugo s.s. The geographical pattern of genetic diversity has recently been described for P. uncinata (Dzialuk et al, 2009), and a lack of genetic differentiation between $P$. uncinata and P. mugo s.s. has been observed in the Alps (Monteleone et al., 2006). However, the phylogeographic history of the species complex has so far not been investigated at a larger geographical scale. We genotyped 29 populations of mountain pine morphologically classified as P. mugo s.s., P. uncinata or P. rotundatal $P . \times$ pseudopumilio, using three (out of 18 tested) hypervariable chloroplast DNA microsatellites (cpSSRs) that resolved 100 haplotypes. In particular, we (1) tested whether morpho-
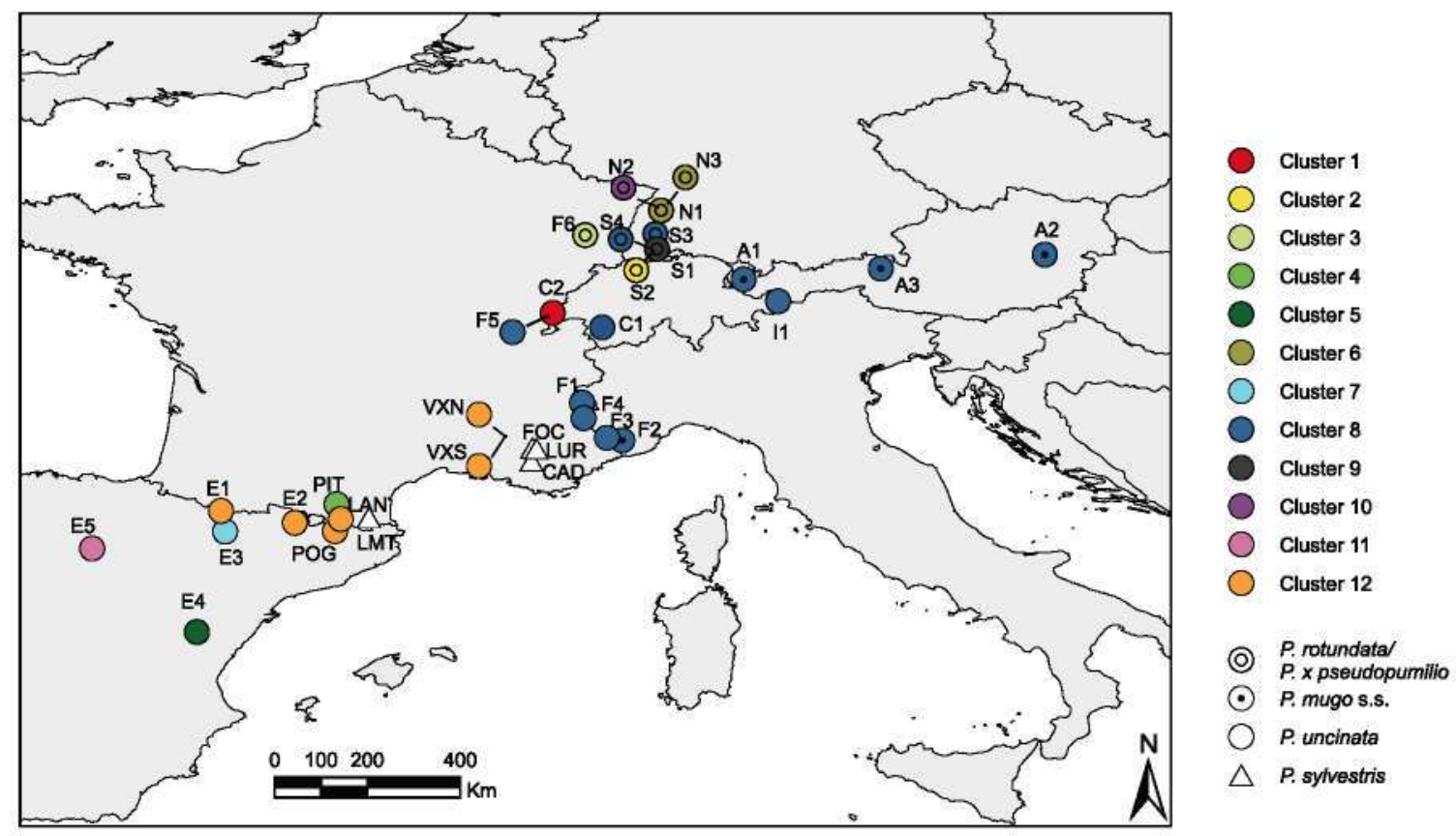

Figure 1 Results of the spatial Bayesian cluster analysis, BAPS, showing genetically homogenous groups of populations of the Pinus mugo species complex in western Europe. 
logically identified species were genetically differentiated, (2) checked for the presence of genetically homogeneous clusters of populations, and (3) investigated historical demographic processes operating in populations. We also genotyped four populations of $P$. sylvestris sampled in the vicinity of $P$. uncinat $\pi$, aiming to evaluate in situ hybridization.

\section{MATERIALS AND METHODS}

\section{Plant material and cPSSR genotyping}

A total of 786 individual trees were sampled from 29 natural populations of P. mugo s.l. located in the Iberian System, the Pyrenees, the French Mont Ventoux, Vosges and Jura mountains, the German Black Forest and throughout the Alps (Fig. 1, Tables l \& 2). Populations were morphologically classified as P. uncimata, $P$. mugo s.s. or P. rotundatal P. $\times$ psendopumilio. Bog-affected populations of the northern Black Forest are generally polycormic (P. $\times$ pseidopumilio), whereas those of the southern Black Forest are generally monocormic ( $P$, rotundata), but they were treated here as the same species category as they have similar ecology, occur in geographical proximity and their taxonomy is very uncertain. Our sample represents a range-wide sample for $P$. uncinata, but covers only the western part of the distribution of $P$. mugo s.s. and of $P$. rotundatalP. $\times$ pseudopunilio. Populations from the Alps and Pyrenees are relatively extensive and can be considered core populations, whereas the peripheral populations grow in more fragmented parts of the range.

Samples consisted of silica-dried needles or seeds; the latter were germinated before DNA extraction from the embryo. Because we suspected introgression of chloroplast DNA (cpDNA) haplotypes through hybridization with P. sylvestris, 85 individuals of $P$. sylvestris from four populations were also sampled at a distance of $<60 \mathrm{~km}$ from two $P$. mugo s.l. populations (Fig. 1, Tables 1 \& 2). DNA was extracted using the DNeasy ${ }^{\mathrm{TM}}$ Plant Mini Kit (Qiagen, Hilden, Germany) and amplified separately at three patemally inherited cpSSRs

Table 1 Characteristics of sampled populations of the Pints inugo species complex in western Europe. Latitude and longitude are given in decimal degrees.

\begin{tabular}{|c|c|c|c|c|c|c|c|}
\hline Species & ID & Locality & Latitude & Longitude & Region & Site & Elevation $(m)$ \\
\hline P. mugo s.s. & $\mathrm{F} 2$ & Mont Ourne & $N 44.10$ & E 7.53 & Alpes Maritimes (France) & Mineral soil & $2100-2200$ \\
\hline P. mugo s.s. & Al & Kellaspitze & $\mathrm{N} 47.22$ & E 9.88 & Lechtaler Alpen (Austria) & Mineral soil & $1900-2000$ \\
\hline P. mugo s.s. & A3 & Wildseeloder & $\mathrm{N} 47.43$ & E 12.54 & Kitzbübler Alpen (Austria) & Mineral soil & $1700-1800$ \\
\hline P. mugo s.s. & A2 & Raxalpe & N 47.70 & E 15.72 & Stejermark (Austria) & Mineral soil & $1700-1900$ \\
\hline P. rotsitdatn & F6 & Bas Beillard & N 48.08 & E 6.81 & Vosges (France) & Bog & 600 \\
\hline P. rotundata & $\$ 2$ & Ibacher Moor & $\mathrm{N} 47.72$ & E 8.07 & Southern Black Forest (Germany) & Bog & 910 \\
\hline P. rotundata & $\$ 4$ & Rotmeer & N 47.87 & E 8.10 & Southern Black Forest (Germany) & Bog & 965 \\
\hline P. rotundata & $\$ 3$ & Briglirain & $\mathrm{N} 48.10$ & E 8.17 & Southern Black Forest (Gernany) & Bog & 990 \\
\hline P. rotsistatn & S1 & Steerenmoos & N 47.81 & E 8.20 & Southern Black Forest (Germany) & Bog & 1000 \\
\hline P. $\times$ pseudopumilio & N1 & Grosses Muhr & N 48.62 & E 8.21 & Northern Black Forest (Germany) & Bog & 1060 \\
\hline P. $\times$ pseisdopumilio & $\mathrm{N} 2$ & Saumisse & N 48.56 & E 8.28 & Northern Black Forest (Gemany) & Bog & 895 \\
\hline P. $\times$ pseudopumilio & $\mathrm{N} 3$ & Hoblohsee & $\mathrm{N} 48.70$ & E 8.42 & Northern Black Forest (Germany) & Bog & 981 \\
\hline P. uncinatu & E5 & Vinuesa & $\mathrm{N} 42.00$ & W 2.75 & Sierra de Cebollera, Soria (Spain) & Mineral soil & $1900-2100$ \\
\hline P. uncinata & $\mathrm{E} 4$ & Alcalá de la Selva & $N 40.38$ & W 0.72 & Sierra de Gúdar, Teruel (Spain) & Mineral soil & $1800-2000$ \\
\hline P. uncintata & E1 & Panticosa & $\mathrm{N} 42.73$ & W 0.25 & Pirineos Centrales (Spain) & Mineral soil & $1600-2200$ \\
\hline P. uncintata & E3 & Sierra de Guara & $\mathrm{N} 42.33$ & W 0.17 & Prepirineos (Spain) & Mineral soil & $1800-2000$ \\
\hline P. uncinata & E2 & Llavorsi & N 42.50 & E 1.18 & Pirineos Orientales (Spain) & Mineral soil & $1600-2200$ \\
\hline P. uncinata & POG & La Molina & $\mathrm{N} \mathrm{42.34}$ & E 1.96 & Pirineos Orientales (Spain) & Mineral soil & $1600-2200$ \\
\hline P. uncinatu & PIT & Pinet & N 42.86 & E 1.99 & Pyrénées orientales (France) & Bog & 800 \\
\hline P. uncinata & LAN & Les Angles & $\mathrm{N} 42.57$ & E 2.07 & Pyrénées orientales (France) & Mineral soil & 1800 \\
\hline P. uncinata & $\mathrm{VXN}$ & Ventoux sud & $\mathrm{N} 44.17$ & E 5.25 & Provence (France) & Mineral soil & 1700 \\
\hline P. uncintata & VXS & Ventoux nord & N 44.18 & E 5.27 & Provence (France) & Mineral soil & 1500 \\
\hline P. uncintata & F5 & Les Rousses & N 46.50 & E 6.08 & Jura Mountains (France) & Bog & 1060 \\
\hline P. uncintata & $\mathrm{C2}$ & Vallée de Joux & N 46.57 & E 6.18 & Jura Mountains (Switzerland) & Bog & 1040 \\
\hline P. uncinatu & Fl & Le Blétonnet & N 44.83 & E 6.75 & Hautes Alpes (France) & Mineral soil & $2100-2200$ \\
\hline P. uncinata & F4 & Pinatelle & $\mathrm{N} 44.53$ & E 6.78 & Alpes de Haute-Provence (France) & Mineral soil & $1700-2000$ \\
\hline P. uncinata & $C 1$ & Solalex & N 46.29 & E 7.14 & Berner Alpen (Switzerland) & Mineral soil & $1670-1810$ \\
\hline P. uncinata & F3 & Col de Salèse & N 44.15 & E 7.23 & Alpes Maritimes (France) & Mineral soil & $1800-2000$ \\
\hline P. uncintata & I1 & Endkopf & N 46.80 & E 10.55 & Ötztaler Alpen (Italy) & Mineral soil & $1900-2000$ \\
\hline P. syluestris & LMT & La Matte & $\mathrm{N} \mathrm{42.60}$ & E 2.62 & Pyrénées orientales (France) & Mineral soil & 1550 \\
\hline P. syluestris & CAI & Cadaraclue & $\mathrm{N} 43.70$ & E 5.77 & Provence (France) & Mineral soil & 300 \\
\hline P. syluestris & FOC & Forcalquier & $N 43.95$ & E 5.78 & Provence (France) & Mineral soil & 500 \\
\hline P. sylvestris & LUR & Lure & N 43.93 & E 5.87 & Provence (France) & Mineral soil & 450 \\
\hline
\end{tabular}


Table 2 Diversity and differentiation statistics of the Pinus mugo species complex in western Europe. BAPS group: cluster assigned in the Bayesian analysis of population structure (see text); $n$ : sample size; $A_{\mathrm{R}}(13)$ : allelic richness based on a sample size of $n=13 ; H_{\mathrm{E}}$ : haplotypic diversity; mean pairwise $F_{\mathrm{ST}}$ : average differentiation between the focal population and all other populations measured with $F_{\mathrm{ST}}$; no. pairwise $F_{\mathrm{ST}}$ with $P<0.05$ : number of pairwise differentiation tests significant at a level of 0.05 after Bonferroni correction; $\bar{D}_{\mathrm{sh}}^{2}(i, j)$ : genetic distance between haplotypes within populations (see text for definition).

\begin{tabular}{|c|c|c|c|c|c|c|c|c|c|c|c|c|}
\hline & ID & Population & Species & $\begin{array}{l}\text { BAPS } \\
\text { group* }\end{array}$ & $n$ & $\begin{array}{l}\text { No. } \\
\text { haplotypes }\end{array}$ & $\begin{array}{l}\text { No. } \\
\text { private } \\
\text { haplotypes }\end{array}$ & $A_{\mathrm{R}}(13)$ & $H_{\mathrm{E}}$ & $\begin{array}{l}\text { Mean } \\
\text { pairwise } F_{\mathrm{ST}}\end{array}$ & $\begin{array}{l}\text { No. pairwise } F_{S T} \\
\text { with } P<0.05\end{array}$ & $\bar{D}_{\mathrm{sh}}^{2}(i, i)$ \\
\hline \multicolumn{13}{|l|}{ Core populations } \\
\hline \multirow[t]{9}{*}{ Alps } & A2 & Steiermark (Austria) & P. mugo s.s. & A & 24 & 13 & 0 & 7.57 & 0.913 & 0.040 & 9 & 0.92 \\
\hline & Al & Lechtaler Alpen (Austria) & P. mugo s.s. & A & 24 & 16 & 1 & 9.01 & 0.946 & 0.027 & 7 & 2.82 \\
\hline & A3 & Kitzbühler Alpen (Austria) & P. mugo s.s. & A & 24 & 14 & 1 & 8.24 & 0.931 & 0.038 & 6 & 1.98 \\
\hline & Il & Ötztaler Alpen (Italy) & P. uncinatia & A & 24 & 12 & 0 & 7.77 & 0.931 & 0.047 & 12 & 1.04 \\
\hline & $\mathrm{Cl}$ & Bemer Alpen (Switzerland) & P. whintata & A & 24 & 15 & 2 & 9.03 & 0.957 & 0.039 & 8 & 2.35 \\
\hline & Fl & Hautes Alpes (France) & P. uncinata & A & 24 & 14 & 0 & 8.08 & 0.909 & 0.050 & 7 & 1.43 \\
\hline & $\mathrm{F}_{2}$ & Alpes Maritimes (France) & P. mugo s.s. & A & 24 & 15 & 3 & 8.97 & 0.953 & 0.052 & 11 & 1.51 \\
\hline & F3 & Alpes Maritimes (France) & P. uncinata & A & 48 & 27 & 4 & 9.76 & 0.966 & 0.036 & 6 & 5.39 \\
\hline & $\mathrm{F} 4$ & Alpes de Haute-Provence (France) & P. untinata & A & 24 & 12 & 1 & 6.85 & 0.851 & 0.064 & 8 & 0.89 \\
\hline \multirow[t]{4}{*}{ Pyrenees } & El & Pirineos Centrales (Spain) & P. uncinata & $\mathrm{P}$ & 21 & 12 & 2 & 7.73 & 0.919 & 0.036 & 6 & 4.93 \\
\hline & E2 & Pirineos Orientales (Spain) & P. utcinata & $\mathbf{P}$ & 22 & 8 & 0 & 5.75 & 0.879 & 0.059 & 11 & 1.91 \\
\hline & POG & Pirineos Orientales (Spain) & P. uncinatia & $\mathrm{P}$ & 24 & 11 & 0 & 7.27 & 0.924 & 0.038 & 10 & 0.99 \\
\hline & LAN & Pyrénées Orientales (France) & P. whtinata & $\mathbf{P}$ & 28 & 13 & 2 & 7.31 & 0.915 & 0.040 & 11 & 1.13 \\
\hline \multirow[t]{2}{*}{ Mont Ventoux } & VXN & Provence (France) & P. uncinata & $\mathrm{A} / \mathrm{P}$ & 17 & 10 & 1 & 7.49 & 0.919 & 0.060 & 8 & 4.78 \\
\hline & VXs & Provence (France) & P. utcintata & $\mathrm{A} / \mathrm{P}$ & 13 & 10 & 3 & 9.00 & 0.962 & 0.036 & 7 & 19.1 \\
\hline \multicolumn{13}{|c|}{ Peripheral populations } \\
\hline \multirow[t]{7}{*}{ Black Forest } & s1 & Southern Black Forest (Germany) & P. rotustdatn & & 48 & 25 & 7 & 9.39 & 0.959 & 0.061 & 24 & 2.21 \\
\hline & \$2 & Southern Black Forest (Germany) & P. rotundata & & 24 & 6 & 0 & 4.23 & 0.808 & 0.084 & 14 & 0.49 \\
\hline & s3 & Southem Black Forest (Germany) & P. rotustdatn & A & 24 & 13 & 2 & 8.40 & 0.946 & 0.048 & 9 & 4.92 \\
\hline & $\$ 4$ & Southern Black Forest (Germany) & P. rotundata & A & 24 & 10 & 1 & 6.57 & 0.895 & 0.074 & 17 & 0.93 \\
\hline & N1 & Northem Black Forest (Germany) & P. $\times$ psestdopumilio & NBF & 24 & 12 & 4 & 7.49 & 0.913 & 0.087 & 27 & 1.48 \\
\hline & $\mathrm{N} 2$ & Northern Black Forest (Germany) & P. $\times$ pseudopumilio & & 24 & 8 & 0 & 4.77 & 0.786 & 0.108 & 20 & 0.85 \\
\hline & N3 & Northern Black Forest (Germany) & P. $\times$ pseusdopumilio & NBF & 24 & 11 & 0 & 7.25 & 0.917 & 0.054 & 10 & 1.57 \\
\hline \multirow[t]{2}{*}{ Jura Mountains } & F5 & Jura Mountains (France) & P. uncinatia & A & 24 & 10 & 0 & 6.34 & 0.862 & 0.102 & 23 & 0.79 \\
\hline & $\mathrm{C} 2$ & Jura Mountains (Switzerland) & P. untcinata & & 24 & 17 & 3 & 9.74 & 0.967 & 0.057 & 16 & 2.53 \\
\hline Vosges & F6 & Vosges (France) & P. rotundata & & 24 & 10 & 1 & 6.03 & 0.815 & 0.085 & 14 & 2.07 \\
\hline \multirow[t]{2}{*}{ Pyrenees } & E3 & Prepirineos (Spain) & P. untintata & & 23 & 9 & 3 & 5.46 & 0.810 & 0.125 & 25 & 1.47 \\
\hline & PIT & Pyrénées Orientales (France) & P. untinata & & 91 & 8 & 2 & 3.43 & 0.758 & 0.123 & 28 & 2.06 \\
\hline \multirow[t]{2}{*}{ Iberian System } & E4 & Sierra de Gúdar (Spain) & P. uncinata & & 21 & 5 & 1 & 3.44 & 0.748 & 0.152 & 24 & 5.56 \\
\hline & E5 & Sierra de Cebollera (Spain) & P. uncinatal & & 22 & 7 & 6 & 5.20 & 0.866 & 0.115 & 28 & 5.86 \\
\hline \multirow[t]{5}{*}{ All P. mugo s.l. } & & & P. muga s.l. & & 786 & 100 & & 10.44 & 0.956 & & & \\
\hline & LMT & Pyrénées orientales (France) & P. sylvestris & & 33 & 18 & 7 & 8.53 & 0.939 & 0.022 & 1 & 1.61 \\
\hline & CAD & Provence (France) & P. sylvestris & & 17 & 6 & 0 & 4.67 & 0.846 & 0.016 & 0 & 0.60 \\
\hline & FOC & Provence (France) & P. sylvestris & & 18 & 7 & l & 5.30 & 0.863 & 0.023 & 1 & 1.03 \\
\hline & LUR & Provence (France) & P. sylvestris & & 17 & 14 & 2 & 10.13 & 0.971 & -0.007 & 0 & 1.90 \\
\hline All P. sylvestris & & & P. sylvestris & & 85 & 23 & & 8.74 & 0.922 & & & \\
\hline
\end{tabular}

${ }^{*}$ A, Alpine cluster (cluster 8 in Fig. 1); P, Pyrenean cluster (cluster 12 in Fig. 1); NBF, northern Black Forest duster (duster 6 in Fig. 1). 
(Mogensen, 1996): Pt15169, Pt41093 and Pt71936 originally isolated from Pinus thunbergii (Vendramin et al, 1996). These loci were chosen for their high polymorphism and nonoverlapping product sizes out of 18 loci tested (Schmid, 2000; Appendix Sl in Supporting Information). The $25-\mu \mathrm{L}$ mix for polymerase chain reaction (PCR) contained $0.2 \mathrm{~mm}$ of each dNTP, $2.5 \mathrm{~mm} \mathrm{MgCl}, 0.2 \mathrm{~mm}$ of each primer (the forward primer being labelled with a fluorescent dye), $10 \times$ reaction buffer (GE Healthcare, Waukesha, WI, USA), $25 \mathrm{ng}$ of DNA and 1 unit Taq polymerase (GE Healthcare). PCR conditions were $5 \mathrm{~min}$ at $95^{\circ} \mathrm{C}, 25$ cycles of $1 \mathrm{~min}$ at $94^{\circ} \mathrm{C}, 1 \mathrm{~min}$ at $55^{\circ} \mathrm{C}, 1 \mathrm{~min}$ at $72{ }^{\circ} \mathrm{C}$, with a final step of $8 \mathrm{~min}$ at $72{ }^{\circ} \mathrm{C}$. Amplification products of the three loci were mixed, separated on an ALF sequencer (GE Healthcare) and sized by comparison with internal size standards of 50,100 and $200 \mathrm{bp}$ using the software Fragment Manager ver. 1.2 (GE Healthcare).

\section{Genetic diversity analysis}

In order to characterize polymorphism in each population, we recorded the number of haplotypes and the number of population-specific (i.e. private or endemic) haplotypes, and we estimated rarefied haplotypic richness, which is the number of haplotypes expected in each population for a standardized sample size ( 13 individuals in our case), using the program RAREFAC (Petit et al, 1998). The program SPAGeDr (Hardy \& Vekemans, 2002) was used to compute haplotypic diversity, $H$, corrected for small sample size. In order to estimate divergence between haplotypes within populations, we computed the average distance $\bar{D}_{\mathrm{sh}}^{2}(i, j)$ between all pairs of individuals $i$ and $j$, defining the distance between the haplotypes carried by $i$ and $j$ according to a microsatellite stepwise mutation model (Echt et al, 1998; Vendramin et al, 1998):

$$
D_{\mathrm{sl}}^{2}(i, j)=K^{-1}\left[\sum_{k=1}^{K}\left|a_{i k}-a_{j k}\right|\right]^{2} .
$$

where $a_{i k}$ and $a_{i k}$ are the allele sizes of the haplotypes carried by $i$ and $j$ at the $k$ th microsatellite region, and $K=3$ is the number of microsatellite regions analysed. This distance is based on the Goldstein et al. (1995) distance, but treats the non-recombinant chloroplast genome as a single locus (Echt et al, 1998; Vendramin et al, 1998).

\section{Genetic structure analyses}

To evaluate the strength of differentiation of each population from all others, we report the number of significant exact tests of pairwise population differentiation based on haplotype frequencies $\left(F_{\mathrm{ST}}\right)$. Exact tests were computed in ARLEQUIN ver. 3.1 (Excoffier et al., 2005), and a sequential Bonferroni correction (Rice, 1989) was applied. A hierarchical analysis of molecular variance (AMOVA) of haplotype frequencies, implemented in ARLEQUIN ver. 3.1, was used to assess (1) differentiation among species and populations within species, and (2) differentiation among geographical regions (Iberian
System, Pyrenees, Alps, and all populations north of the Alps) and among populations within regions.

SPAGEDI was used to compute overall among-population differentiation based on unordered $\left(G_{\mathrm{ST}}\right)$ or ordered $\left(N_{\mathrm{ST}}\right)$ alleles. For the estimation of $N_{\mathrm{ST}}$, a distance matrix between all pairs of haplotypes was computed, defining distances between haplotyes as above. The significance of the two differentiation statistics was tested with 10,000 permutations of individuals among populations. Phylogeographic structure, namely whether phylogenetically close haplotypes are found together in the same population more often than randomly chosen ones (Pons \& Petit, 1996), was investigated by comparing $N_{\mathrm{ST}}$ with the distribution of $N_{S T}$ in 10,000 permutations of haplotype distances among pairs of haplotypes (Hardy et al., 2003).

The overall geographical structure of genetic diversity was analysed using Bayesian analysis of population structure (BAPS, implemented in the program BAPS ver. 5.1, Corander et al, 2003). We applied both a non-spatial and a spatial genetic mixture analysis (Corander et al., 2008) to groups (sampled populations) of haplotypes. These methods use a Markov chain Monte Carlo simulation approach to group population samples into variable user-defined numbers $K$ of clusters. The best partition of populations into $K$ clusters is identified as the one with the highest marginal log-likelihood. We carried out 10 repetitions of the algorithm for each $K$ ranging between 1 and 29. Finally, to test for isolation by distance in the whole dataset and various subsets (see Results), Mantel tests were conducted between the matrices of pairwise genetic differentiation $\left[F_{S \mathrm{~T}} /\left(1-\mathrm{F}_{S \mathrm{~T}}\right)\right]$ and of the logarithm of pairwise geographical distances among populations (Rousset, 1997).

\section{Demographic inferences from genetic data}

We applied a series of analyses to identify signs of population expansion and date them in the P. mugo s.1, dataset, excluding potentially introgressed haplotypes. In an expanding population, the genealogy of a random sample of gene sequences is star-shaped, characterized by short internodes and long terminal branches (Slatkin \& Hudson, 1991). New mutations on these branches result in a relative abundance of rare alleles or haplotypes, compared with populations of stationary size. Fu's $F_{S}$-test statistic is sensitive to such an excess of rare haplotypes and takes a large negative value in expanding populations ( $\mathrm{Fu}, 1997$ ). We used ARLEQUIN ver. 3.1 to test for the significance of Fu's $F_{S}$. For this, we coded cpSSR data in a binary way, representing for each locus the number of repeats of the largest variant with ' $l$ 's and replacing the absent repeats of shorter variants with ' 0 's. Owing to a particular behaviour of the $F_{\mathrm{S}}$-statistic, a test with $P<0.02$ was considered evidence for population expansion at the significance level of $\alpha=0.05$ (Fu, 1997).

We also examined the shape of the distribution of pairwise size differences between haplotypes within populations. We refer to this as a 'mismatch distribution', as is common practice in the literature (Harpending et al, 1993), although 
size differences do not strictly correspond to nucleotide mismatches. Mismatch distributions in expanding populations are typically monomodal (Slatkin \& Hudson, 1991), whereas they are ragged and multimodal in populations with a stationary size. From the mismatch distribution, the population growth parameters $\tau=2 \mu t$ (expansion time), $\Theta_{0}=2 \mu N_{0}$ (initial population size scaled by mutation rate) and $\Theta_{1}=2 \mu N_{1}$ (present population size scaled by mutation rate), where $\mu$ is the mutation rate, $t$ the number of generations since population expansion and $N_{0}$ and $N_{1}$ the population sizes before and after expansion (Rogers \& Harpending, 1992), can be estimated following the procedure of Schneider \& Excoffier (1999). Navascués et al. (2006) have shown that the accuracy of parameter estimates decreases if there is homoplasy in the data, as is common for cpSSRs (Provan et al, 2001). We used their new maximum pseudo-likelihood estimation procedure for population growth parameters that takes homoplasy into account, implemented in the program LMSE (Navascués et al, 2009).

\section{RESULTS}

\section{Levels and structure of genetic diversity}

The numbers of size variants identified at the loci Pt15169, Pt41093 and Pt71936 in P. mugo s.l. were 9, 14 and 8, respectively. They combined into 100 haplotypes (see Table $\$ 1$ ), resulting in a high total haplotypic diversity of $H_{\mathrm{E}}=0.96$ (Table 2). In the four $P$. sylvestris populations, the same loci displayed 5, 4 and 7 size variants, which resolved 23 haplotypes (see Table S2). The variant size ranges were roughly the same in both species for locus Pt71936. For locus Pt15169, $P$. sylvestris carried mostly variants $[127,128$ and 129 base pairs (bp), range 126-130 bp] that corresponded to the upper part of the variant size range found in P. mugo s.l. (range: $119-129 \mathrm{bp}$ ). For locus Pt41093, the common variants in P. sylvestris (77 and $78 \mathrm{bp}$, range: $76-79 \mathrm{bp}$ ) corresponded to the shorter variants of $P$. mugo s.l. (range: 77-92 bp). Eight P. mugo s.l. individuals displayed a total of seven haplotypes characterized by a long variant at Pt 15169 and a short variant at Pt41093, indicating that they might be introgressed from P. sylvestris. Four of these haplotypes were indeed shared between the two species; they occurred in P. nugo s.l. populations VXS (haplotypes 84,88 and 100 ), F3 (haplotype 88) and PIT (haplotype 94). The shared haplotypes of the VXS population from southern Mont Ventoux occurred in the $P$. sylvestris populations $\mathrm{CAD}, \mathrm{FOC}$ and $\mathrm{LUR}$, which are all within $60 \mathrm{~km}$ of VXS, but not in the $P$. sylvestris population from the Pyrenees. The three other suspected introgressed haplotypes occurred in population VXS (haplotype 97), and in the two Spanish populations E1 (haplotype 99) and E4 (haplotype 95), where P. uncinata and P. sylvestris grow sympatrically. The $P$. mugo s.l. populations with (suspected) introgressed haplotypes were generally among those with the highest divergence between haplotypes $\left[\bar{D}_{\text {sh }}^{2}(i, j)\right.$ around 5 or higher, Table 2].
The $P$. mugo s.l. populations with the lowest diversity, displaying an allelic richness of 5.5 haplotypes or fewer in a random sample of 13 individuals (Table 2), were peripheral: E3-E5 in Spain, PIT in southern France, and N2 and S2 from the Black Forest. Together with additional populations from the Black Forest, these populations also showed the highest number of significant pairwise differentiation tests (Table 2). Conversely, the most polymorphic populations, displaying an allelic richness of over eight haplotypes, belonged mostly to the Alpine range of $P$. mugo s.l., and these populations were also among the least differentiated.

In a hierarchical AMOVA framework, species belonging to $P$. mugo s.l. were not significantly differentiated from each other in the sampled range $\left(F_{\mathrm{CT}}=-0.004, P>0.05\right)$, but populations were significantly differentiated within species $\left(F_{\mathrm{SC}}=0.078, P<0.001\right)$. Geographical regions were significantly differentiated $\left(F_{\mathrm{CT}}=0.013, P<0.05\right)$, as were populations within regions $\left(F_{\mathrm{SC}}=0.069, P<0.001\right)$. These results indicate that geography is a stronger determinant of genetic structure at cpSSRs in the sampled range of $P$. migo s.l. than taxonomy (see also below). In the overall dataset, amongpopulation differentiation was $F_{\mathrm{ST}}=0.076$ and $G_{\mathrm{ST}}=0.070$ based on unordered alleles, and $N_{\mathrm{ST}}=0.263$ based on ordered alleles (all three statistics significant with $P<0.001$ ). The test for phylogeographic structure was significant $\left[N_{\mathrm{ST}}>N_{\mathrm{ST}}\right.$ (permuted), $P<0.001$ ).

We applied a Bayesian analysis of population structure to characterize the overall structure of genetic diversity in P. migo s.l. Results were similar using either a non-spatial or a spatial model for genetic mixture analysis; the best partition contained 14 or 12 clusters, respectively. A large cluster of Alpine populations and a smaller one of Pyrenean populations were identified (clusters 8 and 12 for the spatial model, Fig. 1), whereas most other populations were found in single-population clusters. In the spatial model, the Mont Ventoux populations clustered within the Pyrenean cluster. In the nonspatial model, the eastern Pyrenean populations LAN and POG and the southern Mont Ventoux population VXS clustered within the Alpine cluster, indicating some haplotype sharing with the Alpine range. Differentiation analysis was also carried out in the Alpine and Pyrenean clusters defined from the spatial BAPS analysis (Fig. 1). Populations from the Pyrenean cluster were not significantly differentiated based on unordered alleles $\left(G_{\mathrm{ST}}=0.005, P>0.05\right)$, although they were using ordered alleles $\left(N_{\mathrm{ST}}=0.139, P<0.001\right)$, essentially as a result of the features of the above-mentioned VXS population. Differentiation in the Alpine cluster was weak but significant $\left[G_{\mathrm{ST}}=0.036, P<0.001 ; N_{\mathrm{ST}}=0.130, P<0.001 ; N_{\mathrm{ST}}>N_{\mathrm{ST}}\right.$ (permuted), $P=0.001]$. Populations of $P$. mingo s.s. were not significantly differentiated from populations of $P$. ancinata within the Alps $\left(F_{\mathrm{CT}}=-0.003, P>0.05\right.$ ), but populations within both species were significantly differentiated ( $\left.F_{S C}=0.020, P<0.001\right)$. It is also worth noting that the seven populations within the Black Forest belonged to five distinct clusters (Fig. 1); hence they were strongly differentiated despite the short spatial distance separating them 
$\left[G_{\mathrm{ST}}=0.085, \quad N_{\mathrm{ST}}=0.337, \quad N_{\mathrm{ST}}>N_{\mathrm{ST}} \quad\right.$ (permuted), all $P<0.001]$. Tests for isolation by distance were marginally significant in the overall dataset $(P=0.088)$ but non-significant in the Pyrenean and in the Alpine BAPS clusters and in the Black Forest.

\section{Demographic inferences from genetic data}

Fu's $F_{\mathcal{S}}$-test for population expansion was significant in most core populations, but in only a few peripheral populations (Table 3). Mismatch distributions were monomodal or slightly wavy for Alpine and Pyrenean populations, but very irregular for most peripheral populations, in particular for those with low genetic diversity (Fig. 2). This suggests that core and peripheral populations of $P$. mugo s.l. have had different demographic histories. In the Alps, roughly two types of populations could be distinguished: those with strictly monomodal mismatch distributions ( $\mathrm{Il}, \mathrm{A} 2, \mathrm{~F} 4$, and to a lesser extent $F 1$ and $F 2$ ), and those with wavy, bimodal distributions (A1, A3, C1, F3). The latter were able to maintain a lineage with short variants (81-83 bp) at locus Pt41093 and might represent old populations. The Pyrenean populations' mismatch distributions were all wavy, and, again, this pattern was caused by the geographical distribution of a short variant ( $85 \mathrm{bp)}$ ) at locus Pt4l093 (Fig. 2). Values of the time of expansion $\tau$ varied about 3 -fold in Alpine and Pyrenean populations but oscillated around the same values, $1.9<\tau<5.5$ (Table 3), which suggests similar expansion times in these two ranges. Interpretations in terms of years since expansion are subject to the imprecision with which mutation rates are known for cpSSRs in pines. If a low mutation rate of $\mu=10^{-5}$ (Provan et al, 1999) and a long generation time of 100 years (as in Navascués et al., 2006) are assumed for the average $\tau=3.56$, the Alpine/Pyrenean expansion could be as old as $18 \times 10^{6}$ years. A high mutation rate $\left(\mu=10^{-3}\right)$, suggested by the high diversity found in cpSSRs of European pine species (e.g. Robledo-Arnuncio et al, 2005), and a short generation time of 25 years (as in Brown et al, 2004) would still place the expansion at 44,500 years ago. Hence, the genetic signs of expansion resulted from demographic events that pre-dated the LGM. Our results also suggest that the current effective population size of $P$. migo in core populations $\left(1.3 \times 10^{5}<\Theta_{1}<2.1 \times 10^{13}\right)$ was larger than that in expanding peripheral populations $\left(36.5<\Theta_{1}<7.6 \times 10^{5}\right)$.

\section{DISCUSSION}

\section{Absence of species differentiation in Pinus mugo s.l.}

The high morphological variation and adaptation to different ecological conditions in the $P$. mugo complex gave rise to the delimitation of the species P. uncinata, P. migo s.s. and P. rotundata (Businský, 1999), which have numerous synonyms (Hamerník \& Musil, 2007). Genetic variation at neutral cpSSRs was high in P. migo s.L, $H_{\mathrm{E}}=0.96$, similar to or higher than in other conifers in Central Europe or the Mediterranean Basin (Gómez et al., 2005; Robledo-Arnuncio et al, 2005; Terrab et al, 2006). Genetic variation was, however, not structured according to morphology, but according to geography. In particular, Alpine populations of $P$. uncinata and P. mugo s.s. belonged to a nearly homogeneous gene pool at cPSSR markers, indicating a common history and homogenizing gene flow. This result is in agreement with the absence of differentiation between 15 Alpine populations of P. uncnata and $P$. mugo s.s. at nuclear random amplified polynorphic DNA markers (Monteleone et al., 2006), and with a smaller allozyme differentiation between Alpine $P$. uncinata and $P$. mugo s.s. than among $P$, rotundata populations from the Black Forest (Schmid, 2000). Moreover, Lewandowski et al. (2000) identified only weak allozyme differentiation between populations belonging to different taxa from the $P$. migo complex. These results suggest that different growth forms and ecological adaptations evolved in different parts of the distribution range of the complex and were maintained despite the existence of extensive gene flow (Sambatti \& Rice, 2006; Savolainen et al., 2007). The evolution of local adaptations and the ensuing high taxonomic diversity paralleled with low genetic differentiation at neutral markers seem to be a common pattern in pines (e.g. Barbéro et al, 1998; Savolainen et al, 2007). For instance, Flora Europaea lists 26 varieties for P. sylvestris (Gaussen et al, 1993) and differentiation is strong for quantitative traits (García-Gil et al, 2003), but cpSSR and allozyme differentiation are weak over large parts of the range (both c. 7\%; Cheddadi et al, 2006; Wang et al., 2008). Similarly, in maritime pine, Pinus pinaster Ait., at least three subspecies are recognized (Barbéro et al, 1998), and quantitative traits are much more strongly differentiated than allozymes (González-Martínez et al, 2002) or cpSSRs (Bucci et al. 2007). These observations suggest that adaptations in pines probably rest on a few genes while the majority of the genome shows only weak differentiation and reflects essentially demographic history (Scotti-Saintagne et al, 2004; GonzálezMartínez et al,, 2008).

\section{Phylogeographic structure}

The pattern of differentiation we identified in the surveyed range of $P$. mugo s.l. was weak $\left(G_{S \mathrm{~T}}=0.07\right)$, but had a clear phylogeographic structure $\left[N_{S \mathrm{~T}}=0.263, N_{\mathrm{ST}}>N_{\mathrm{ST}}\right.$ (permuted), $P<0.001$ ], with vicariant gene pools in the Pyrenees and Alps and several smaller genetic clusters corresponding mostly to marginal populations. This differentiation pattern suggests that different historical and possibly adaptation processes affected central versus peripheral populations of P. mugo s.l. in the studied range. Our results are completely congruent with a recently published phylogeographic study of P. uminata, which also reports a homogeneous Pyrenean gene pool and strongly differentiated populations in the Iberian System (Dzialuk et al, 2009). Although macrofossil data provided unambiguous support for glacial refugia of $P$. mugo s.l. only in the Alps and in the Czech Republic, differentiated 
Table 3 Tests for population expansion and estimation of denographic parameters in populations of the Pints mago species conplex in western Europe. BAPS group: cluster assigned in the Bayesian analysis of population structure (see text); Fu's test: test of population expansion (Fu, 1997); Population growth parameters (with homoplasy): maximum pseudo-likelihood method of Navascués et al. (2009) to estimate ancestral $\left(\Theta_{0}\right)$ and current $\left(\Theta_{1}\right)$ population sizes, scaled by mutation rate, and the number of generations $(\tau)$ since the beginning of expansion, scaled by mutation rate; $-\log [\mathrm{CL}]$ : likelihood of the model; n.a.: method not applied because Fu's test was non-significant.

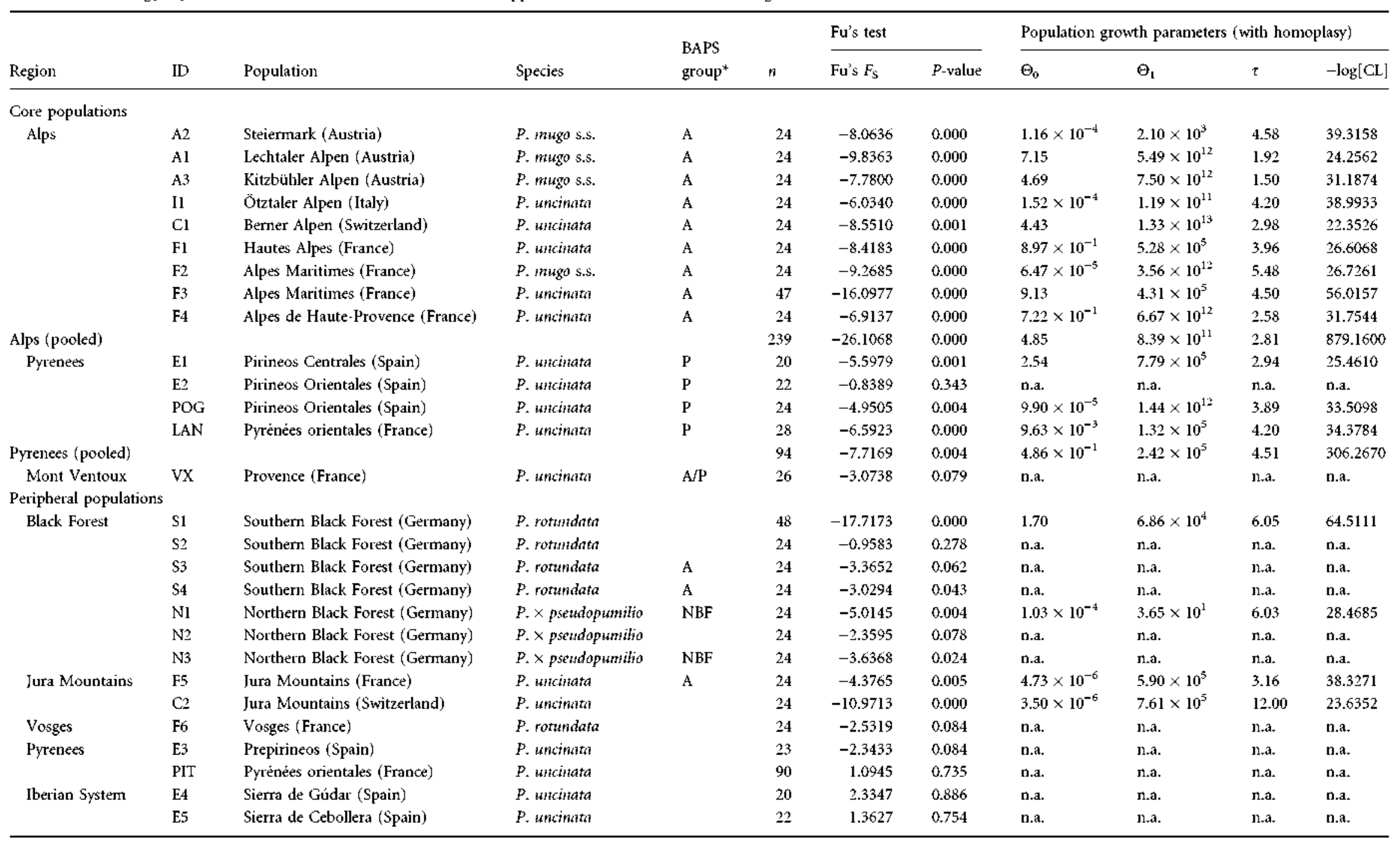

${ }^{*}$ A, Alpine cluster (cluster 8 in Fig. 1); P. Pyrenean cluster (cluster 12 in Fig. 1); NBF, northern Black Forest cluster (cluster 6 in Fig. 1). 

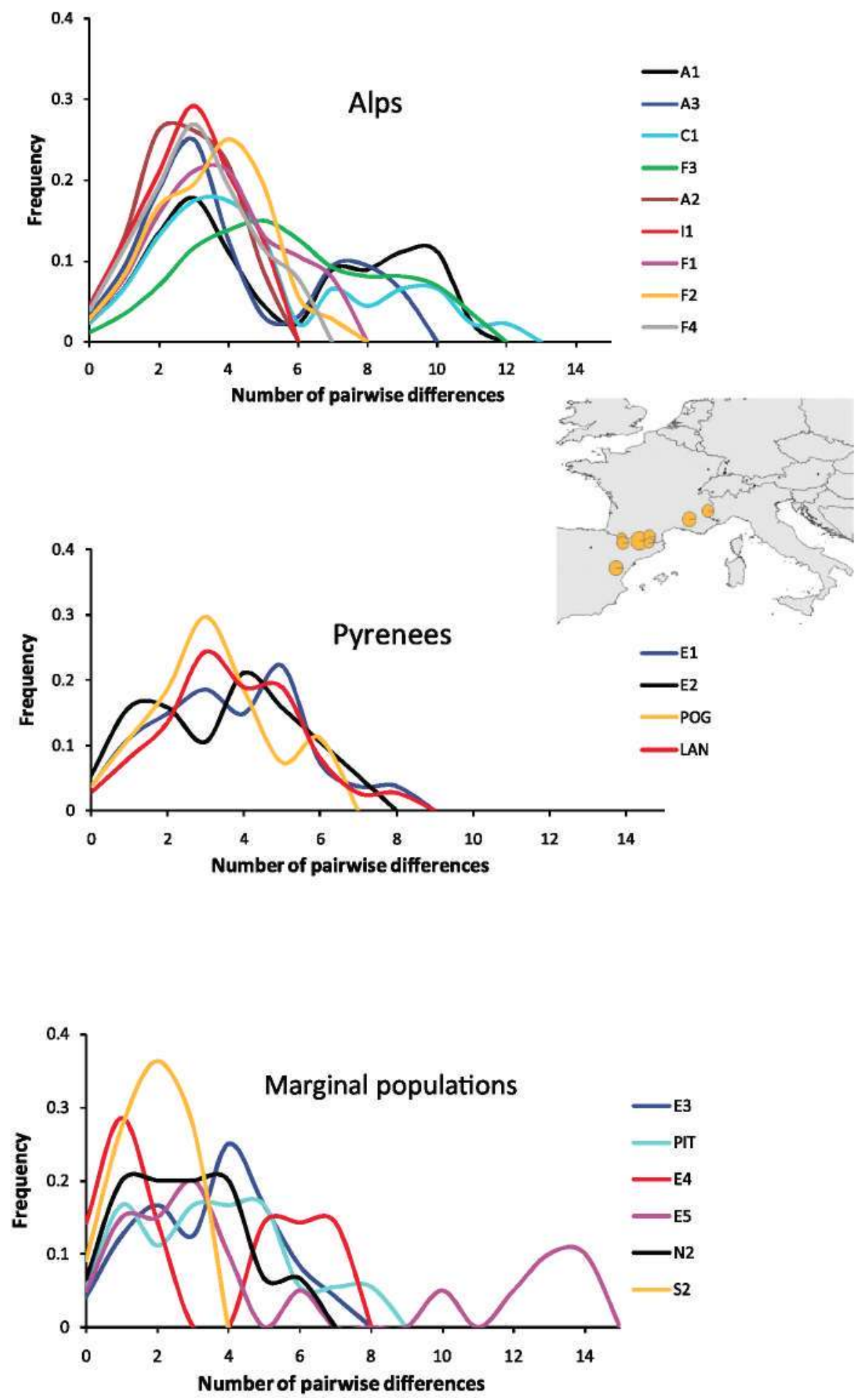

Figure 2 Mismatch distributions of Alpine (top), Pyrenean (middle) and marginal (i.e. peripheral with low diversity, see text) (bottom) populations of the Pinus mugo species complex in western Europe. The inset map shows the distribution of the 85-bp variant at Pt40196.

gene pools in the Alps and Pyrenees suggest colonization of both mountain ranges from independent glacial refugia. A third major vicariant gene pool for P. mugo s.s. might lie within the Balkan Peninsula (not surveyed in our study), where Slavov \& Zhelev (2004) found only very weak differentiation among populations, $F_{\mathrm{ST}}=0.04$, using allozymes (see also Feurdean et al., 2007). Distinct vicariant gene pools on major mountain chains have also been identified for other conifers of the region, for instance for Abies alba Mill. (Vendramin et al., 1999), P. nigra (Afzal-Rafii \& Dodd, 2007) 
and Pinus cembra (Höhn et al., 2009). For P. nigra, differentiated peripheral populations were also observed (Afzal-Rafii \& Dodd, 2007).

Our cpSSR data revealed signatures of population expansion pre-dating the LGM (c. 18,000 $\mathrm{yr}$ вP) in Alpine and Pyrenean populations of the $P$. mugo complex. Palaeobotanical evidence indicates that P. sylvestris/P. migo s.l. was present in Europe throughout the Pleistocene cold stages and interglacials (West, 1980; Field et al., 2000) and spread early in the post-glacial period from a wide range of locations, including sites in the Iberian Peninsula, the Alps, the Hungarian plains and the Carpathians (Cheddadi et al, 2006; see also the Introduction). Given that average Weichselian temperatures were higher than in the LGM (van Andel, 2002; Van Meerbeeck et al, 2009), the earlier spread suggested by our genetic data is conceivable, but supporting quantitative palaeobotanical data are not available, to our knowledge. Similarly to the case for P. migo s.l., bottlenecks followed by population expansion were detected in Eurosiberian, cold-adapted conifers based on nuclear DNA sequence data (dated to $150,000-300,000$ yT BP in Picea abies, Heuertz et al, 2006; to c. $2 \mathrm{Myr}$ вP in P. sylvestris, Pyhäjärvi et al, 2007).

Within the Alpine and Pyrenean P. mugo s.l. gene pools, overall genetic structure (measured with $G_{\mathrm{ST}}$ ) was weak or absent, but phylogeographic structure $\left[N_{\mathrm{ST}}>N_{\mathrm{ST}}\right.$ (permuted)] was discovered in each mountain range. These results suggest that each mountain chain was probably colonized by a different series of historically differentiated glacial populations, which became well connected by pollen flow within mountain chains at the latest during post-glacial recolonization, but possibly earlier (see also Liepelt et al., 2002; Heuertz et al, 2004). In the Alps, good candidates for a long-term glacial refugium are the western Alpine populations F2 and F3, harbouring a total of seven endemic haplotypes (see Refugium I of Schönswetter et al., 2005). Populations that were probably old, as indicated by divergent lineages [i.e. populations with high $\bar{D}_{\mathrm{sh}}^{2}(i, j)$, bimodal mismatch distributions, and/or numerous high pairwise $N_{\mathrm{ST}}$-values (results not shown)], were widely spread throughout the Alps, from west $(\mathrm{Cl}, \mathrm{F} 2$ and $\mathrm{F} 3)$ to east (I1, A1 and A3), on southern (F2) or northern flanks (F4, A3), suggesting that colonization of the chain may have happened from west, south, east and north. Fossil pollen data are in agreement with early post-glacial recolonization from the south and the north-west in the Swiss Alps (Burga, 1988). In the Pyrenees, our sampling was fairly limited; however, populations from west and east of the range harboured endemic haplotypes (El and LAN), indicating that, similarly to in the Alps, multiple populations may have contributed to the colonization of the current range. More differentiated maternally inherited mitochondrial DNA data (e.g. Liepelt et al., 2002) might provide further information on locations of glacial refugia in areas where cPSSR data are weakly differentiated. However, the mitochondrial region nad3-rpS12, containing microsatellite variation in Pinis species (Soranzo et al., 1999), was monomorphic in the surveyed P. migo s.l. range (Schmid, 2000).
The $P$, rotundato $P . \times$ psendopumilio populations native to disjunct bog habitats of the Black Forest had very variable levels of genetic diversity and were strongly differentiated, despite occurring within a small geographical region (the maximum distance between populations was $112 \mathrm{~km}$ ). The highly divergent gene pools identified by BAPS suggest multiple origins, including a genetic connection between the southern Black Forest and the Alps. High diversity and the presence of endemic haplotypes suggest old age and large population sizes in Steerenmoos (S1), Briglirain (S3) and Grosses Muhr (N1), whereas low diversity indicates strong genetic drift in Saumisse (N2) and Ibacher Moor (S2). The small bog-affected pine populations (typically 2-12 ha, mapped by P. von Sengbusch, University of Freiburg, pers. comm., 2004) are nowadays separated by silver fir and spruce forests (Dierssen \& Dierssen, 1984) that inhibit gene flow among them, leading to genetic drift. Selection by the local environment may also have contributed to the high differentiation. As in other regions, Pinus showed early post-glacial expansion and subsequent decline in the Black Forest (pollen core of the $\$ 1$ population, Rösch, 2000). Furthermore, human impact has been intense in the region since about $7600 \mathrm{yr} \mathrm{BP}$, and the present-day bog pine populations seemed to have expanded only after medieval burning (Rösch, 2000, and references therein). Additional distinct gene pools were identified in bog-affected populations: in the isolated population from the French Vosges (F6), in the Jura (with some Alpine influence, Fig. 1, Table 3) and in the French eastern Pyrenees (PIT). Overall, these data suggest multiple glacial P. migo s.l. populations north of the Alps and probably the Рyтenees, which kept their genetic distinctiveness despite late glacial and early Holocene expansion.

The marginal populations of the Iberian Peninsula, namely Prepirineos (E3), Sierra de Gúdar (E4) and Sierra de Cebollera (E5), were the most differentiated populations, all harbouring endemic haplotypes and lacking evidence of population expansion. These results are in agreement with a model of long genetic isolation, probably through several glacial cycles (Dzialuk et al, 2009), with populations experiencing elevational shifts but no considerable growth in size. RobledoArnuncio et al. (2005) showed that P. sylvestris also responded to climate oscillations by elevational shifts in northern Spain, but, in contrast to $P$. Ininata, it maintained large population sizes. Large $P$. sylvestris glacial populations survived in drainage basins, which connected the individual mountain blocks to which the species retreated during warm stages (RobledoArnuncio et al, 2005). It is possible that the occupation of the plains by $P$. sylvestris prevented the establishment of $P$. uncinata at lower elevations during cold stages, contributing to the presently observed differentiation in P. uncinata.

\section{Haplotype sharing between P. mugo s.l. and P. sylvestris}

We found evidence of haplotype sharing between P. sylvestris and $P$. mugo s.l, which could result from hybridization or 
sharing of ancestral haplotypes, given that the species are closely related (Filppula et al, 1992). They are also partially interfertile, but the incidence of natural hybridization seems to be very low (Christensen, 1987b). In controlled crosses (Wachowiak et al., 2005) and under natural conditions (Wachowiak \& Prus-Glowacki, 2008), viable offspring were obtained between the two species only when $P$. mugo s.l. was the pollen donor. However, our finding of P. sylvestris haplotypes in P. mugo s.l. would rather suggest $P$. sylvestris to be the pollen donor. Whether our results reflect true introgression from $P$. sylvestris into $P$. mugo is debatable, as the detection power is hampered by our use of few markers and by the suggested high levels of homoplasy of cpSSRs (Provan et al, 2001). In Spain, the much more abundant P. sylvestris may literally swamp marginal P. uncinato populations with its pollen. Therefore, the issue of introgression is important for the conservation and evolution of P. mugo s.l. and requires more attention in future research.

\section{Identification of conservation priorities}

It is predicted that in the Iberian Peninsula, montane conifer species such as $P$. sylvestris and $P$. uncinata will suffer intense and rapid reductions of their distribution ranges in the future because global warming will induce their migration to higher elevations, but such areas of sufficient elevation are not available for colonization (Benito Garzón et al, 2008). The P. uninata populations in Sierra de Cebollera and Sierra de Gúdar are in this situation. These populations are strongly differentiated, and, as southern 'rear edge' populations, they may harbour important adaptations relevant to the conservation of the species (Dynesius \& Jansson, 2000; Hampe \& Petit, 2005). The $P$. ancinata population from Sierra de Cebollera is showing signals of expansion owing to lower grazing pressure and increased mean temperatures; however, recruitment patterns are significantly influenced by the availability of suitable habitats for germination at the edges of Colluna vulgaris mats (Camarero et al., 2005) and high minimum September temperatures (Camarero \& Gutiérrez, 2007). This suggests that biotic interactions and nonlinear responses of species to temperature need to be considered when predicting the effects of climate change (Davis et al, 1998). In particular, research on competitive interactions and on the pattern of gene flow between P. uncinata and P. sylvestris is required in order to understand the effects of the climate-driven invasion of $P$. uncinata populations by $P$. sylvestris on low mountains in Spain. The genetic distinctiveness of $P$. uncinata populations from the Iberian System further justifies conservation measures. In these low mountains in situ conservation seems challenging, and ex situ conservation of seed lots and live collections is urgently needed.

In the Black Forest, many P. rotundata/P. $\times$ pseudopumilio populations show considerable dieback and insufficient natural regeneration. These seem to be delayed consequences of the drainage of bogs for peat collection (von Sengbusch, 2002). After at least 200 years of regular burning of peat bogs in the
Black Forest, fire disturbance has ceased, reducing the availability of open habitats for bog pine regeneration. At the same time, the lowering of water levels has allowed the establishment of a dense undergrowth and invasion of the drier bog margins by the shade-tolerant Picen abies (von Sengbusch, 2002). Lower water levels also trigger a plastic response towards a more slender growth habit in straight-stemmed bog pines in the southen Black Forest, which makes the trees more prone to mechanical stress owing to winter snow cover and winds, enhancing the dieback (von Sengbusch, 2002). Because global warming is projected to aggravate the dieback, and these populations are genetically distinct, conservation measures are justified and necessary. A combined strategy of in situ conservation of the larger bogs along with the establishment of $e x$ situ collections is recommended.

\section{ACKNOWLEDGEMENTS}

This work is part of the $\mathrm{PhD}$ thesis of J.T. (nee Schmid), funded by the German Evangelisches Studienwerk e.V. Villigst. Additional support from the EVOLTREE EU-funded Network of Excellence (http:/www.evoltree.eu), the Spanish Ministry of Environment (CC03-048 and AEG06-054), the Spanish National Research Plan (REN 2000-1617-GLO) and the French Ministry of Ecology (DIREN Languedoc - Roussillon) is also acknowledged. We thank Pascal von Sengbusch for ecological information on the Black Forest populations, and Anna Buonamici, Jeanne Bodin and Carmen García for technical assistance in the lab. Thanks are extended to Felix Gugerli, to J. Julio Camarero, to the editor, P. Linder, and to three anonymous referees for providing useful comments on previous versions of the manuscript, and to P. C. Grant, for assistance with the editing of the manuscript. M.H. acknowledges a post-doctoral contract of the National Fund for Scientific Research of Belgium (FRS-FNRS) and an FNRSfunded scientific visit to CIFOR-INIA.

\section{REFERENCES}

Afzal-Rafii, Z. \& Dodd, R.S. (2007) Chloroplast DNA supports a hypothesis of glacial refugia over post-glacial recolonization in disjunct populations of black pine (Pinus nigra) in western Europe. Molecular Ecology, 16, 723-736.

Aguinagalde, I., Hampe, A., Mohanty, A., Martín, J.P., Duminil, J. \& Petit, R. (2005) Effects of life-history traits and species distribution on genetic structure at maternally inherited markers in European trees and shrubs. Journal of Biogeography, 32, 329-339.

Aguirre-Planter, E, Furnier, G.R. \& Eguiarte, L.E. (2000) Low levels of genetic variation within and high levels of genetic differentiation among populations of species of Abies from southern Mexico and Guatemala. American Journal of Botany, 87, 362-371.

Ali, A.A., Carcaillet, C., Guendon, J.-L., Quinif, Y., Roiron, P. \& Terral, J.-F. (2003) The Early Holocene treeline in 
the southern French Alps: new evidence from travertine formations. Global Ecology and Biogeography, 12, 411-419.

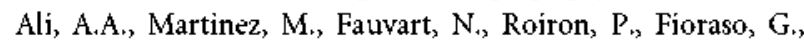
Guendon, J.-L,, Terral, J.-F, \& Carcaillet, C. (2006) Incendies et peuplements à Pinus Imıgo Turra dans les Alpes occidentales (Val de Suse, Italie) durant la transition Tardiglaciaire-Holocène: une zone refuge évidente. Comptes Rendis Biologies, 329, 494-501.

van Andel, T.H. (2002) The climate and landscape of the middle part of Weichselian Glaciation in Europe: the stage 3 project. Quatemary Research, 57, 2-8.

Barbéro, M, Loisel, R, Quézel, P., Richardson, D.M. \& Romane, F. (1998) Pines of the Mediterranean Basin. Ecology and biogeography of Pinus (ed. by D.M. Richardson), pp. 153-170. Cambridge University Press, Cambridge.

Benito Garzón, M, Sánchez de Dios, R, \& Sainz Ollero, H. (2008) Effects of climate change on the distribution of Iberian tree species. Applied Vegetation Science, 11, 169-178.

Boratyńska, K. \& Boratyński, A. (2007) Taxonomic differences among closely related pines Pinus sylvestris, P. inugo, $P$. uncinata, $P$. rotumiato and $P$. uliginosa as revealed in needle sclerenchyma cells. Flora, 202, 555-569.

Brown, G.R., Gill, G.P., Kuntz, R.J., Langley, C.H. \& Neale, D.B. (2004) Nucleotide variation and linkage disequilibrium in loblolly pine. Proceedings of the National Academy of Sciences USA, 101, 15255-15260.

Bucci, G., González-Martínez, S.C., Le Provost, G., Plomion, C., Ribeiro, M.M., Sebastiani, F., Alía, R. \& Vendramin, G.G. (2007) Range-wide phylogeography and genetic zones in Pinus pinaster Ait. revealed by chloroplast microsatellite markers. Molecular Ecology, 16, 2137-2153.

Burga, C.A. (1988) Swiss vegetation history during the last 18000 years. New Phytologist, 110, 581-602.

Businský, R. (1999) Taxonomická studie agregátu Pinus mugo a jeho hybridních populací. Acta Prühoniciona, 68, 123-144.

Businský, R. \& Kirschner, J. (2006) Nomenclatural notes on the Pinus mugo complex in Central Europe. Phyton (Horn, Austria), 46, 129-139.

Camarero, J.J. \& Gutiérrez, E. (2007) Response of Pinus uncinata recruitment to climate warming and changes in grazing pressure in an isolated population of the Iberian System (NE Spain). Arctic, Antarctic and Alpine Research, 39, 210-217.

Camarero, J.J., Gutiérrez, E, Fortin, M.J. \& Ribbens, E. (2005) Spatial patterns of tree recruitment in a relict population of Pinus uncinata: forest expansion through stratified diffusion. Journal of Biogeogrophy, 32, 1979-1992.

Cantegrel, R. (1983) Le Pin à crochets pyrénéen: biologie, biochimie, sylviculture. Acta Biologica Montana, 2-3, 87330 .

Carrión, J.S. (2002) Patterns and processes of Late Quaternary environmental change in a montane region of southwestern Europe. Quaternary Science Reviews, 21, 2047-2066.

Cheddadi, R., Vendramin, G.G., Litt, T., François, L., Kageyama, M, Lorentz, S, Laurent, J.-M, de Beaulieu, J.-L,
Sadori, L, Jost, A. \& Lunt, D. (2006) Imprints of glacial refugia in the modern genetic diversity of Pinus sylvestris. Global Ecology and Biogeography, 15, 271-282.

Christensen, K.I. (1987a) Taxonomic revision of the Pinus mugo complex and $P . \times$ rhatica ( $P$. mugo $\times$ sylvestris) (Pinaceae). Nordic Journal of Botony, 7, 383-408.

Christensen, K.I. (1987b) A morphometric study of the Pinis migo Turra complex and its natural hybridization with P. sylvestris L. (Pinaceae). Feddes Repertorium, 98, 623635.

Corander, J., Waldmann, P. \& Sillanpää, M.J. (2003) Bayesian analysis of genetic differentiation between populations. Genetics, 163, 367-374.

Corander, J, Sirén, J. \& Arjas, E. (2008) Bayesian spatial modelling of genetic population structure. Computational Statistics, 23, 111-129.

Davis, M.B. \& Shaw, R.G. (2001) Range shifts and adaptive responses to Quaternary climate change. Science, 292, 673679.

Davis, A.J., Jenkinson, L.S., Lawton, J.H., Shorrocks, B. \& Wood, S. (1998) Making mistakes when predicting shifts in species range in response to global warming. Nature, 391, $783-786$.

Dierssen, B. \& Dierssen, K. (1984) Vegetation und Flora der Schwarzwaldmoore. Beihefte $z u$ den Veröffentlichungen fïr Naturschutz und Landschaftspflege in Baden-Wiirttemberg, $39,1-512$.

Dirnböck, T., Dullinger, S. \& Köck, R. (2008) Organic matter accumulation following Pinus inugo Turra establishment in subalpine pastures. Plant Ecology and Diversity, 1, 59-66.

Dynesius, M. \& Jansson, R. (2000) Evolutionary consequences of changes in species' geographical distributions driven by Milankovitch climate oscillations. Proceedings of the National Acodemy of Sciences USA, 97, 9115-9120.

Dzialuk, A, Muchewicz, E, Boratyński, A, Montserrat, J.M, Boratyńska, K. \& Burczyk, J. (2009) Genetic variation of Pinus uncinato (Pinaceae) in the Pyrenees determined with cPSSR markers. Plant Systematics and Evolution, 277, 197-205.

Echt, C.S., DeVerno, L.L., Anzidei, M. \& Vendramin, G.G. (1998) Chloroplast microsatellites reveal population genetic diversity in red pine, Pinus resinosa Ait. Moleculor Ecology, 7, 307-316.

Eckert, C.G., Samis, K.E. \& Lougheed, S.C. (2008) Genetic variation across species' geographical ranges: the centralmarginal hypothesis and beyond. Molecular Ecology, 17, $1170-1188$.

Excoffier, L., Laval, G. \& Schneider, S. (2005) Arlequin ver. 3.0: an integrated software package for population genetics data analysis. Evolutionary Bioinformatics Online, 1, 47-50.

Feurdean, A., Wohlfarth, B., Björkman, L., Tantau, I., Bennike, O., Willis, K.J., Farcas, S. \& Robertsson, A.M. (2007) The influence of refugial population on Late glacial and early Holocene vegetational changes in Romania. Review of Palaeobotany and Palynology, 145, 305-320. 
Field, M.H, de Beaulieu, J.-L, Guiot, J. \& Ponel, P. (2000) Middle Pleistocene deposits at La Côte, Val-de-Lans, Isère department, France: plant macrofossil, palynological and fossil insect investigations. Palaeogeography, Palaeoclimatology. Palaeoecology, 159, 53-83.

Filppula, S., Szmidt, A.E. \& Savolainen, O. (1992) Genetic comparison between Pinus sylvestris and P. mugo using isozymes and chloroplast DNA. Nordic Journal of Botany, 12, 381-386.

Franco Múgica, F., García Antón, M. \& Sainz Ollero, H. (1998) Vegetation dynamics and human impact in the Sierra de Guadarrama, Central System, Spain. The Holocene, 8, 69-82.

$\mathrm{Fu}$, Y.X. (1997) Statistical tests of neutrality of mutations against population growth, hitchhiking and background selection. Genetics, 147, 915-925.

García-Amorena, I, Gómez Manzaneque, F, Rubiales, J.M, Granja, H.M., Soares de Carvalho, G. \& Morla, C. (2007) The Late Quaternary coastal forests of western Iberia: a study of their macroremains. Palaeogeography, Palaeodimatology, Palaeoecology, 254, 448-461.

García-Gil, M.R., Mikkonen, M. \& Savolainen, O. (2003) Nucleotide diversity at two phytochrome loci along a latitudinal cline in Pinus sylvestris. Molecular Ecology, 12, 11951206.

Gaussen, H, Heywood, V.H. \& Chater, A.O. (1993) Pinus. Flora Europaen, Vol. 1, 2nd edn (ed. by T.G. Tutin, N.A. Burges and A.O. Chaters), pp. 40-44. Cambridge University Press, Cambridge.

Gil García, M.J., Dorado-Valiño, M., Valdeolmillos-Rodríguez, A. \& Ruiz-Zapata, M.B. (2002) Late-glacial and Holocene palaeoclimatic record from Sierra de Cebollera (northern Iberian Range, Spain). Quatemary International, 93-94, 1318.

Goldstein, D.B., Ruiz-Linares, A, Cavalli-Sforza, L.L. \& Feldman, M.W. (1995) An evaluation of genetic distances for use with microsatellite loci. Genetics, 139, 463-471.

Gómez, A, Vendramin, G.G., González-Martínez, S.C. \& Alía, R. (2005) Genetic diversity and differentiation of two Mediterranean pines (Pinus halepensis Mill. and Pinus pinaster Ait.) along a latitudinal cline using chloroplast microsatellite markers. Diversity and Distributions, 11, 257263.

González-Martínez, S.C., Alía, R. \& Gil, L. (2002) Population genetic structure in a Mediterranean pine (Pinus pinaster Ait.): a comparison of allozyme markers and quantitative traits. Heredity, 89, 199-206.

González-Martínez, S.C, Huber, D, Ersoz, E, Davis, J.M. \& Neale, D.B. (2008) Association genetics in Pints taeda L. II. Carbon isotope discrimination. Heredity, 101, 19-26.

Hamerník, J. \& Musil, I. (2007) The Pinis migo complex - its structuring and general overview of the used nomenclature. Journal of Forest Science, 53, 253-266.

Hampe, A. \& Petit, R.J. (2005) Conserving biodiversity under climate change: the rear edge matters. Ecology Letters, 8, $461-467$.
Hardy, O.J. \& Vekemans, X. (2002) SPAGeDi: a versatile compute program to analyse spatial genetic structure at the individual or population levels. Molecular Ecology Notes, 2, $618-620$.

Hardy, O.J., Charbonnel, N., Freville, H. \& Heuertz, M. (2003) Microsatellite allele sizes: a simple test to assess their significance. Genetics, 163, 1467-1482.

Harpending, H.C., Sherry, S.T., Rogers, A.R. \& Stoneking, M. (1993) The genetic structure of ancient human populations. Current Anthropology, 34, 483-496.

Heuertz, M., Hausman, J.F., Hardy, O.J., Vendramin, G.G., Frascaria-Lacoste, N. \& Vekemans, X. (2004) Nuclear microsatellites reveal contrasting patterns of genetic structure between western and southeastern European populations of the common ash (Fraxinus excelsior L.). Evolution, 58, 976-988.

Heuertz, M., De Paoli, E., Källman, T., Larsson, H., Jurman, I., Morgante, M., Lascoux, M. \& Gyllenstrand, N. (2006) Multilocus patterns of nucleotide diversity, linkage disequilibrium and demographic history of Norway spruce (Picea abies [L.] Karst). Genetics, 174, 2095-2105.

Höhn, M., Gugerli, F., Abran, P., Bisztray, G., Buonamici, A., Cseke, K., Hufinagel, L., Sebastiani, F, Quintela-Sabarís, C. \& Vendramin, G.G. (2009) Variation in the chloroplast DNA of Swiss stone pine (Pinus cembra L.) reflects contrasting post-glacial history of populations from the Carpathians and the Alps. Journal of Biogeography, 36, 1798-1806.

Jaramillo-Correa, J.P., Aguirre-Planter, E., Khasa, D.P., Egujarte, L.E., Piñero, D., Furnier, G.R. \& Bousquet, J. (2008) Ancestry and divergence of subtropical montane forest isolates: molecular biogeography of the genus Abies (Pinaceae) in southern México and Guatemala. Molecular Ecology, 17, 2476-2490.

Lewandowski, A., Boratyński, A. \& Mejnartowicz, L. (2000) Allozyme investigations on the genetic differentiation between closely related pines - Pinus sylvestris, $P$. inugo, P. uncinata and P. uliginosa (Pinaceae). Plant Systematics and Evolution, 221, 15-24.

Liepelt, S, Bialozyt, R. \& Ziegenhagen, B. (2002) Winddispersed pollen mediates post-glacial gene flow among refugia. Proceedings of the National Academy of Sciences USA, 99, 14590-14594.

Maliouchenko, O., Palmé, A.E., Buonamici, A., Vendramin, G.G. \& Lascoux, M. (2007) Comparative phylogeography of two European birch species, Betula pendula and B. pubescens, with high level of haplotype sharing. Journal of Biogeography, 34, 1601-1610.

Marcysiak, K. \& Boratyński, A. (2007) A contribution to the taxonomy of Pinus incinato (Pinaceae) based on cone characters. Plant Systematics and Evolution, 264, 57-73.

Mogensen, H.L. (1996) The hows and whys of cytoplasmic inheritance in seed plants. American Jourial of Botany, 83, 383-404.

Monteleone, I., Ferrazzini, D. \& Belletti, P. (2006) Effectiveness of neutral RAPD markers to detect genetic divergence 
between the subspecies uncinata and mugo of Pinus mugo Turra. Silva Fennica, 40, 391-406.

Navascués, $M$, Vaxevanidou, Z., González-Martínez, S.C., Climent, J., Gil, L. \& Emerson, B.C. (2006) Chloroplast microsatellites reveal colonization and metapopulation dynamics in the Canary Island pine. Molecular Ecology, 15, 2691-2698.

Navascués, M., Hardy, O.J. \& Burgarella, C. (2009) Characterization of demographic expansions from pairwise comparisons of linked microsatellite haplotypes. Genetics, 181, 1013-1019.

Ozenda, P. (1988) Die Vegetation der Alpen im europäischen Gebirgsraum. Gustav Fischer, Stuttgart.

Petit, R.J, El-Mousadik, A. \& Pons, O. (1998) Identifying populations for conservation on the basis of genetic markers. Conservation Biology, 12, 844-855.

Petit, R.J., Aguinagalde, I., de Beaulieu, J.L., Bittkau, C., Brewer, S., Cheddadi, R., Ennos, R., Fineschi, S., Grivet, D., Lascoux, M., Mohanty, A., Muller-Starck, G., DemesureMusch, B., Palmé, A., Pedro Marti, J., Rendell, S. \& Vendramin, G.G. (2003) Glacial refuges: hotspots but not melting pots of genetic diversity. Science, 300, 1563-1565.

Pons, A. \& Reille, M. (1988) The Holocene and upper Pleistocene pollen record from Padul (Granada, Spain): a new study. Palaeogeography, Palaeoclimatology, Palaeoecology, 66, 243-263.

Pons, O. \& Petit, R.J. (1996) Measuring and testing genetic differentiation with ordered versus unordered alleles. Genetics, 144, 1237-1245.

Provan, J., Soranzo, N., Wilson, N.J., Goldstein, D.B. \& Powell, W. (1999) A low mutation rate for chloroplast microsatellites. Genetics, 153, 943-947.

Provan, I, Powell, W. \& Hollingsworth, P.M. (2001) Chloroplast microsatellites: new tools for studies in plant ecology and evolution. Trends in Ecology and Evolution, 16, 142-147.

Pyhäjärvi, T, García-Gil, M.R, Knürr, T, Mikkonen, M, Wachowiak, W. \& Savolainen, O. (2007) Demographic history has influenced nucleotide diversity in European Pinus sylvestris populations. Genetics, 177, 1713-1724.

Ramil-Rego, P., Muñoz-Sobrino, C., Rodríguez-Guitián, M. \& Gómez-Orellana, L. (1998) Differences in the vegetation of the North Iberian Peninsula during the last 16,000 years. Plait Ecology, 138, 41-62.

Rice, W.R. (1989) Analyzing tables of statistical tests. Evolution, 43, 223-225.

Robledo-Arnuncio, J.J., Collada, C., Alía, R, \& Gil, L. (2005) Genetic structure of montane isolates of Pinus sylvestris $\mathrm{L}$. in a Mediterranean refugial area. Journal of Biogeography, 32, 595-605.

Rogers, A.R. \& Harpending, H. (1992) Population growth makes waves in the distribution of pairwise genetic differences. Molecular Biology and Evolution, 9, 552-569.

Rösch, M. (2000) Long-term human impact as registered in an upland pollen profile from the southern Black Forest, southwestern Germany. Vegetation History and Archaeobotany, 9, 205-218.
Rousset, F. (1997) Genetic differentiation and estimation of gene flow from $F$-statistics under isolation by distance. Genetics, 145, 1219-1228.

Sambatti, J.B. \& Rice, K.J. (2006) Local adaptation, patterns of selection, and gene flow in the Californian serpentine sunflower (Helianthus exilis). Evolution, 60, 696-710.

Sandoz, H. (1983) Sur la plausibilité de l'installation de refuges pléistocènes du Pin mugho ou Pin pumilo (Pinus mughis Scopoli = Pinis pumilio Haenke) dans la basse vallée de la Durance (Provence occidentale - France). Revue Générale de Botanique, 90, 23-41.

Savolainen, O, Pyhäjärvi, T. \& Knürr, T. (2007) Gene flow and local adaptation in trees. Anmual Review of Ecology, Evolution, and Systematics, 38, 595-619.

Schmid, J. (2000) DNA- und Isoenzym-Polymorphismen in Populationen des Berg-Kiefern-Komplex, Pinus mugo Turra s.l. PhD Thesis, Albert-Ludwigs-University, Freiburg.

Schmid, J. \& Bogenrieder, A. (1998) Spirken-Moorwälder im Schwarzwald. Das Steeremmoos bei Faulenfürst (Gemeinde Schluchsee). Mitteilungen des Badischen Landesvereins für Naturkinde und Naturschitz N.F. 17, 1, 29-58.

Schneider, S. \& Excoffier, L. (1999) Estimation of past demographic parameters from the distribution of pairwise differences when the mutation rates vary among sites: application to human mitochondrial DNA. Genetics, 152, 1079-1089.

Schönswetter, P., Stehlik, I, Holderegger, R. \& Tribsch, A. (2005) Molecular evidence for glacial refugia of mountain plants in the European Alps. Molecular Ecology, 14, 35473555.

Scotti-Saintagne, C., Mariette, S., Porth, I., Goicoechea, P.G., Barreneche, T., Bodénès, C., Burg, K. \& Kremer, A. (2004) Genome scanning for interspecific differentiation between two closely related oak species [Quercus robur L, and Q. petraen (Matt.) Liebl.]. Genetics, 168, 1615-1626.

von Sengbusch, P. (2002) Untersuchungen zur Ökologie von Pinus rotundata LINK (Moor-Bergkiefer) in Siidschworzwald. PhD Thesis, Albert-Ludwigs-Universität, Freiburg.

Slatkin, M. \& Hudson, R.R. (1991) Pairwise comparisons of mitochondrial DNA sequences in stable and exponentially growing populations. Genetics, 129, 555-562.

Slavov, G.T. \& Zhelev, P. (2004) Allozyme variation, differentiation and inbreeding in populations of Pinis migo in Bulgaria. Conadian Journal of Forest Research, 34, 26112617.

Soranzo, N, Provan, I. \& Powell, W. (1999) An example of microsatellite length variation in the mitochondrial genome of conifers. Genome, 42, 158-161.

Tarasov, P.E., Volkova, V.S., Webb, T., III, Guiot, J., Andreev, A.A., Bezusko, L.G., Bezusko, T.V., Bykova, G.V., Dorofeyuk, N.I., Kvavadze, E.V., Osipova, I.M., Panova, N.K. \& Sevastyanov, D.V. (2000) Last glacial maximum biomes reconstructed from pollen and plant macrofossil data from northem Eurasia. Journal of Biogeography, 27, 609-620.

Terrab, A., Paun, O., Talavera, S., Tremetsberger, K., Arista, M. 8. Stuessy, T.F. (2006) Genetic diversity and population 
structure in natural populations of Moroccan Atlas cedar (Cedrus atlantica; Pinaceae) determined with cpSSR markers. Anerican Journal of Botany, 93, 1274-1280.

Tribsch, A. \& Stuessy, T.F. (2003) Evolution and phylogeography of arctic and alpine plants in Europe: introduction. Taxon, 52, 415-416.

Van Meerbeeck, C.J., Renssen, H. \& Roche, D.M. (2009) How did Marine Isotope Stage 3 and Last Glacial Maximum climates differ? - perspectives from equilibrium simulations. Climate of the Past, 5, 33-51.

Vendramin, G.G., Lelli, L., Rossi, P. \& Morgante, M. (1996) A set of primers for the amplification of 20 chloroplast microsatellites in Pinaceae. Molecular Ecology, 5, 585-598.

Vendramin, G.G., Anzidei, M, Madaghiele, A. \& Bucci, G. (1998) Distribution of genetic diversity in Pinus pinaster Ait. as revealed by chloroplast microsatellites. Theoretical and Applied Genetics, 97, 456-463.

Vendramin, G.G., Degen, B., Petit, R.J., Anzidei, M., Madaghiele, A. \& Ziegenhagen, B. (1999) High level of variation at Abies alba chloroplast microsatellite loci in Europe. Molecular Ecology, 8, 1117-1127.

Wachowiak, W. \& Prus-Glowacki, W. (2008) Hybridisation processes in sympatric populations of pines Pinus sylvestris L, P. mugo Turra and P. uliginosa Neumann. Plant Systematics and Evolution, 271, 29-40.

Wachowiak, W, Lewandowski, A. \& Prus-Glowacki, W. (2005) Reciprocal controlled crosses between Pints sylvestris and $P$. mugo verified by a species-specific cPDNA marker. Journal of Applied Genetics, 46, 41-43.

Wang, X.-R., Szmidt, A.E. \& Lindgren, D. (2008) Allozyme differentiation among populations of Pinis sylvestris (L.) from Sweden and China. Hereditas, 114, 219-226.

West, R.G. (1980) Pleistocene forest history in East Anglia. New Phytologist, 85, 571-622.

Willis, K.J. \& van Andel, T.H. (2004) Trees or no trees? The environments of central and eastern Europe during the last glaciations. Quaternary Science Reviews, 23, 2369-2387.

Willis, K.J., Bennett, K.D. \& Birks, H.J.B. (1998) The late Quaternary dynamics of pines in Europe. Ecology and bio- geography of Pinus (ed. by D.M. Richardson), pp. 107-121. Cambridge University Press, Cambridge.

\section{SUPPORTING INFORMATION}

Additional Supporting Information may be found in the online version of this article:

Appendix S1 Selection of cpSSR loci.

Table S1 Haplotypes observed in the Pinus migo species complex.

Table 52 Haplotypes observed in Pints sylvestris.

Table $\$ 3$ Pinus mugo s.l. sequencing of cpSSR Pt41093.

Table 54 Pairwise $F_{\mathrm{ST}}$-values between populations of the Pinus migo species complex.

As a service to our authors and readers, this journal provides supporting information supplied by the authors. Such materials are peer-reviewed and may be re-organized for online delivery, but are not copy-edited or typeset. Technical support issues arising from supporting information (other than missing files) should be addressed to the authors.

\section{BIOSKETCH}

Myriam Heuertz is a post-doctoral researcher interested in empirical and simulation studies of plant population genetics, with special emphasis on the evolutionary processes that shape diversity and genetic structure at different geographical scales.

Author contributions: J.T., A.S., B.F. and G.G.V. collected the data for this paper; R.A. and G.G.V. obtained the funding; M.H. and S.C.G.M. analysed the data; M.H. led the writing. All authors contributed ideas, comments and revised all manuscript versions.

Editor: Peter Linder 